\title{
Grass, Trees, and Cattle on Clearcut-Logged
}

\section{Areas}

\author{
A. MCLEAN AND M.B. CLARK
}

\begin{abstract}
Generally, the presence of domestic grass had little effect on germination or survival of conifers on clearcut-logged areas, except where the stand of grass became overly dense. In cases where inhibiting effects were apparent, the competition from native vegetation was of as much consequence as the competition from domestic grasses. Results of the study suggest that where numbers of cattle and period of grazing were adequately controlled, damage to lodgepole pine and spruce seedlings were negligible. Damage was a result of repeated trampling rather than browsing. Poor cattle management in some situations resulted in overutilization of forage and large numbers of lodgepole pine seedlings were killed or damaged. However, the number was often insignificant in relation to the mortality of seedlings from natural causes. In a grazing trial the 4-year average daily weight gains were $0.64 \mathrm{~kg}$ for calves and $0.13 \mathrm{~kg}$ for their dams. Using the average weight gains and stocking rates, the pastures returned 60 $\mathrm{kg}$ of $\mathrm{beef} / \mathrm{ha} / \mathrm{yr}$.
\end{abstract}

For many years burned-over areas of forested rangelands in interior British Columbia were seeded to grass, mostly by air. With the increase in clearcut logging, ranchers and the Range Division of the British Columbia Ministry of Forests saw opportunities to use the disturbed areas for forage production. As a result, in the 1960's over 29,000 ha of clearcut logged or burned-over forested rangeland were seeded to mixtures of grasses and legumes for pasture. Conflicts arose over the effects of grazing on the regeneration of tree species. Foresters claimed that poor tree regeneration occurred on many areas because of the destruction of trees through trampling and grazing by cattle, and competition between tree seedlings and grass for moisture. The foresters' concern was understandable since they are obliged to see that cut-over areas are adequately restocked.

To establish the place of seeding grass on clearcuts and determine the effect on tree regeneration, research was undertaken by the Research and Range Divisions of the Ministry of Forests and the Agriculture Canada Research Station at Kamloops (Clark and McLean 1974, 1978); the research reported herein was a continuation of the studies reported in 1974 and discusses the effect of grasses and grazing upon the establishment, survival, and growth of lodgepole pine (Pinus contorta var. latifolia) and Engelmann spruce (Picea engelmannii). Also determined were the volume of forage produced and used, and cattle weight gains under controlled grazing of seeded areas.

\section{Methods}

Between 1971 and 1974, 29 clearcuts of various sizes and postlogging treatments were aerially sown with a mixture of bunchgrasses,

\footnotetext{
The authors are research scientist, Agriculture Canada, Range Research Station; and research forester, Research Division, British Columbia Ministry of Forests, Kamloops, B.C.

Manuscript received September 11, 1978
}

namely, timothy (Phleum pratense), orchardgrass (Dactylis glomerata), and crested wheatgrass (Agropyron desertorum) at $4.5 \mathrm{~kg} / \mathrm{ha}$. Strips, usually $105 \mathrm{~m}$ wide across each clearcut, were left unseeded as controls. Some areas were planted to spruce and/or lodgepole pine; others became restocked with natural regeneration. Twenty-one of these areas were abandoned because of poor grass establishment or distribution, or because of later severe disturbance by fire. Two areas were added later for additional information. Data on grass productivity and forage utilization were collected on areas 1,2, 4, 5, and 8 , and the data on cattle performance on Area 1. Four areas were located in the Engelmann spruce-subalpine fir (Abies lasiocarpa) zone and four in the Interior Douglasfir (Pseudotsuga menziesii) zone (Table 1).

The effect of grass competition on height growth of tree reproduction was measured on two clearcuts with combinations of seeding vs. no seeding and grazing vs. no grazing. At one location (Area 1) 2-year-old lodgepole pine and spruce had been planted in separate but adjacent areas. Six years later, heights were recorded on 100 trees in each treatment. On another clearcut containing natural lodgepole pine regeneration (Area 3), tree heights were recorded after 4 years.

A grazing trial was conducted on a 130-ha area (Area 1) that had been clearcut of lodgepole pine and spruce (Fig. 1). The site had been broadcast burned and restocked with lodgepole pine and spruce before being seeded with a grass-legume mixture by air a year later. A fair stand of grass resulted. The area was divided into three fields for flexibility in grazing and cows and calves were grazed from early July to mid-October. The length of season varied but the 4-year average was 105 days.

The fields were grazed in rotation so that the animals seldom remained on any one field for more than a month. The stocking rates for the experimental fields averaged $0.73 \mathrm{ha} / \mathrm{AUM}$ over 4 years (Table

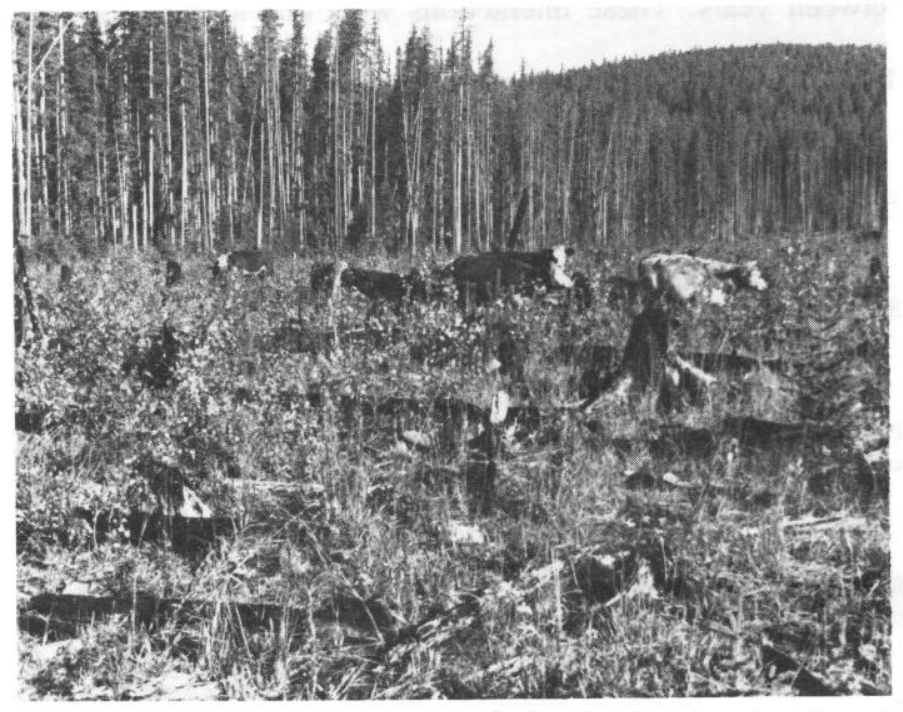

Fig. 1. Cattle grazing a clearcut (Area l) that had been broadcast burned, planted to spruce, and seeded to grass the following year. 
Table 1. Description of study areas.

\begin{tabular}{|c|c|c|c|c|c|c|c|c|c|c|}
\hline \multirow[b]{2}{*}{ Area } & \multirow{2}{*}{$\begin{array}{l}\text { Size } \\
\text { (ha) }\end{array}$} & \multirow{2}{*}{$\begin{array}{l}\text { Biogeo- } \\
\text { climatic } \\
\text { zone }\end{array}$} & \multirow{2}{*}{$\begin{array}{c}\text { Elev. } \\
(\mathrm{m})\end{array}$} & \multirow{2}{*}{$\begin{array}{l}\text { Post-logging } \\
\text { treatment }\end{array}$} & \multicolumn{2}{|c|}{$\begin{array}{c}\text { Area of grass } \\
\text { treatment (ha) }\end{array}$} & \multirow{2}{*}{$\begin{array}{l}\text { Type of } \\
\text { regeneration }\end{array}$} & \multicolumn{2}{|c|}{$\begin{array}{l}\text { Temp. }\left({ }^{\circ} \mathrm{C}\right) \\
\text { May-Oct. } \\
\end{array}$} & \multirow{2}{*}{$\begin{array}{l}\text { Precip. } \\
\text { May-Oct. } \\
\quad(\mathrm{mm})\end{array}$} \\
\hline & & & & & Seeded & Unseeded & & Max. & Min. & \\
\hline 1 & 130 & ESSF $^{1}$ & 1340 & Broadcast-burned & 110 & 20 & $\begin{array}{c}\text { Planted \& } \\
\text { natural }\end{array}$ & 30 & -10 & 187 \\
\hline 2 & 50 & ESSF & 1280 & Broadcast-burned & 40 & 10 & Planted & 30 & -10 & 162 \\
\hline 3 & $\begin{array}{r}12 \\
5\end{array}$ & $\mathrm{IDF}_{a}$ & 1220 & Windrowed-burned & 12 & - & Natural & 31 & -12 & 155 \\
\hline \multirow[t]{5}{*}{4} & $\begin{array}{r}5 \\
20\end{array}$ & $\begin{array}{l}\text { IDF }_{a} \\
\text { ESSF }\end{array}$ & $\begin{array}{l}1220 \\
1435\end{array}$ & $\begin{array}{l}\text { Windrowed-burned } \\
\text { Bunched-burned }\end{array}$ & $\overline{20}$ & $\underline{5}$ & $\begin{array}{l}\text { Natural } \\
\text { Natural }\end{array}$ & - & - & - \\
\hline & 10 & ESSF & 1435 & Scarified & 20 & 10 & Natural & 29 & 9 & 162 \\
\hline & 16 & ESSF & 1400 & Broadcast-burned & 16 & - & Natural & - & - & - \\
\hline & 8 & ESSF & 1370 & Bunched-burned & - & 8 & Natural & - & - & - \\
\hline & 16 & ESSF & 1415 & Bunched-burned & 16 & - & Natural & - & - & - \\
\hline \multirow[t]{2}{*}{5} & 36 & $\mathrm{IDF}_{a}$ & 1370 & Drag-scarified & 36 & - & Natural & 30 & -10 & 162 \\
\hline & 34 & $\mathrm{IDF}_{a}^{a}$ & 1370 & Drag scarified & - & 34 & Natural & - & - & - \\
\hline 6 & 44 & $\mathrm{IDF}_{b}$ & 1190 & Windrowed-burned & 36 & 8 & $\begin{array}{l}\text { Natural and } \\
\text { direct seeding }\end{array}$ & 28 & -4 & 300 \\
\hline & ESSF & 1280 & Windrowed-burned & - & - & Natural & 31 & -11 & 183 \\
\hline \multicolumn{2}{|c|}{$\begin{array}{l}\text { Adational } \\
7 \\
8\end{array}$} & $\mathrm{IDF}_{b}$ & 760 & Wildfire & - & - & Planted & 33 & -4 & 250 \\
\hline
\end{tabular}

'ESSF Engelmann spruce-subalpine fir; $\mathrm{IDF}_{\mathrm{a}}$, Interior Douglas fir; $\mathrm{IDF}_{\mathrm{b}}$, Interior Douglas fir, moist.

5). At this rate the degree of utilization varied between 75 and $85 \%$. The rate was considered heavy and was designed to reveal any damage to trees by livestock.

\section{Results and Discussion}

Germination and growth of grass, and germination and survival of naturally regenerated tree seedlings, were directly affected by weather prevalent during the term of the study. For example, 1973 was one of the driest years on record for the Kamloops Forest District and this contributed to lower than normal herbage production and to higher than average damage by cattle to both coniferous and grass seedlings. Mid-May temperature during 1974 reached an all-time record low for most of the study areas and this, combined with the generally cool and moist spring season, adversely affected grass germination. Frost occurred almost every month during most years of the study at the medium- to high-elevation locations and probably had some adverse effect on grass growth and coniferous seedling establishment. Many interactions between grass, trees, and cattle occurred, between and within areas, between years. These interactions were due to variations in

Table 2. Survival of tree seedlings $(\%)$, proportion of mortality attributed to cattle $(\%)$, and level of stocking of tree seedlings $(\mathrm{No} / \mathrm{ha})$ on four seeded and unseeded areas as measured 4 years after treatment.

\begin{tabular}{|c|c|c|c|c|}
\hline & \multicolumn{4}{|c|}{ Area } \\
\hline & 1 & 3 & 4 & 5 \\
\hline \multicolumn{5}{|c|}{ Survival of tree seedlings $(\%)$} \\
\hline Seeded & $93^{1}$ & 51 & 28 & 35 \\
\hline Unseeded & 95 & 31 & 47 & 51 \\
\hline \multicolumn{5}{|c|}{$\begin{array}{l}\text { Proportion of mortality } \\
\text { caused by cattle }(\%)\end{array}$} \\
\hline Seeded & 27 & 46 & 32 & 49 \\
\hline Unseeded & 30 & 29 & 20 & 56 \\
\hline \multicolumn{5}{|c|}{$\begin{array}{l}\text { Level of stocking of trees } \\
\text { seedlings (No/ha) }\end{array}$} \\
\hline Seeded & planted & 3880 & 1892 & 3052 \\
\hline Unseeded & planted & 1705 & 6110 & 5609 \\
\hline
\end{tabular}

Area 1 values represent survival of planted stock. Areas 3, 4, 5 values represent stocking levels of natural regeneration. soils, elevations, topography, precipitation, temperature, or cattle numbers and management. For this reason the observations on tree damage are discussed by site.

Tree Damage by Cattle

Area I

This 130-ha area was planted with lodgepole pine and spruce during spring 1971. The whole area, less control strip, was sown with a grass-legume mix in late fall 1971. The area was cross-fenced and used for grazing trials. There was no significant difference in cattle-caused mortality of trees between seeded and nonseeded areas, nor was there a significant relationship between cattle-related mortality and degree of utilization of forage. Although a fair proportion of seedling mortality was attributable to cattle, the total loss was immaterial (Table 2).

\section{Area 2}

This 50-ha area was sown to a forage mix in late 1971 and planted with spruce seedlings during fall 1972. Turbulent air conditions caused drift of seed onto the control strip, negating comparative studies. However, plots were established during 1973 to study effects of grazing cattle on the planted spruce.

Cattle grazing was continuous over 4 months of the first summer following planting. This activity resulted in $11 \%$ mortality of tree seedlings as a direct result of cattle damage and an additional $31 \%$ of the remaining seedlings were severely damaged by trampling during the first year.

\section{Area 3}

This location consisted of two adjacent blocks that were windrowed and burned in late 1970. One 12-ha block was sown with a forage mix in late 1971 and the other 5-ha block was left unseeded as a control. Exclosures were established in both blocks. Both blocks restocked to lodgepole pine naturally.

Utilization of forage on the grass-sown area was high each year, averaging $83 \%$ over 3 years as compared with $44 \%$ on the unseeded block. Comparisons of changes in numbers of tree seedlings over the term of the study for seeded, unseeded, grazed and protected sites confirmed the marked effect of cattle on seedling survival (Table 2). The mortality resulting from cattle damage, however, was only from 29 to $46 \%$ (Area 3 ) of 
that resulting from natural causes and rodents. Of specific importance is that, regardless of the cause or amount of mortality, all treatments had a sufficient number of surviving seedlings per hectare for adequate stocking of the area.

Area 4

This location consisted of five clearcut blocks of $20,16,16$, 10 , and 8 ha. The 20-ha block was bunched and burned, one 16-ha block was broadcast burned, and the other was bunched and burned. All above blocks were sown with grasses in late 1971. The 10-ha block, scarified during logging, and the 8-ha block, bunched and burned, were left unseeded. All blocks were left to restock naturally.

Grazing was very heavy during 1973 and 1974. Also, 1973 was very dry. Extensive cattle damage occurred to both forage plants and lodgepole pine seedlings. However, mortality through natural causes was also very high and that which was a direct result of cattle was less than a third of the total (Table 2). Despite the losses all blocks restocked adequately.

There was no consistent evidence of direct competition between tree seedlings and seeded grass. However, effects of interspecific competition were confounded by differences in site preparation between cut blocks, which, in turn, affected seed supply following treatment.

\section{Area 5}

This study area consisted of two clearcut blocks of 36 and 34 ha which were drag-scarified during 1971 . The 36 -ha block was sown with grasses in late 1971 and the 34-ha block was left unseeded. Exclosures were constructed in each block. Both blocks were left to restock naturally.

Although the survival of lodgepole pine seedlings was somewhat affected by grass competition, this was of minor consequence since the grass-seeded areas became adequately stocked with seedlings (Table 2). Similarly, intraspecific competition of lodgepole pine within the unseeded treatments had an effect on number of seedlings surviving but not on actual amount of area stocked to trees. Cattle damage was heavy and contributed to about one-half of the total mortality but this did not materially affect the adequacy of tree stocking.

\section{Area 6}

This 75-ha area was broadcast burned in 1971, sown with grasses, and planted with spruce in fall 1972. Physiological condition of planted stock, weather conditions during planting, and overuse by cattle combined to produce high mortality and poor condition of surviving seedlings. It was impossible, however, to separate the causal factors involved so the area was abandoned for study.

\section{Area 7}

This 44-ha area was windrowed and burned in 1973. In spring 1974, 36 ha were sown to grasses and 8 ha were left unseeded. Plots were established within the two treatments and crossseeded with lodgepole pine in the spring of 1974.

Revegetation of the area with native species masked any effects of sown forage species. Also, cattle use of the area was light from 1974 through 1976 with no damage to seedlings occurring. Number of seedlings establishing was related more to distance of plots from perimeter seed source than to any other factor.

\section{Area 8}

This area, which supported a dense stand of willow (Salix $\mathrm{sp}$ ), was cleared and windrowed in 1971 and sown with the Forest Service grass-legume mix to provide grazing. A combination of a good seedbed for spruce, scattered spruce trees with a good seed crop in 1971, and favorable germination conditions produced a large number of seedlings at the same time as grass establishment. Exclosures were constructed on the area.

Forage utilization by cattle averaged about $70 \%$ over 3 years but varied from 40 to $90 \%$. Mortality of spruce averaged $46 \%$ on unprotected plots with $78 \%$ of this resulting from cattle damage.

\section{Seedling Survival as Affected by Grass Competition and Grazing}

There was no consistent difference in cattle-caused mortality of tree seedlings between grass-seeded and unseeded areas (Table 2), nor was there a significant relationship between cattle-related mortality and degree of utilization of forage. Although a fair proportion of seedling mortality was attributable to cattle, the absolute losses were insignificant for restocking. On four seeded clearcuts the mortality attributed to cattle range from 20 to $56 \%$ of the total mortality. The stocking level for the above two extreme sites was 6,110 and 5,609 trees per hectare respectively (Table 1) suggesting that, in these two extreme cases, cattle damage did not prevent adequate stocking level of trees. Even in two cases where survival was low (28 and $31 \%$ ), the level of stocking was 1,892 and 1,705 seedlings per hectare. The ideal stocking rate on the forest type observed is considered to be about 1,100 to 1,500 well-distributed stems per hectare. The fact that both the highest and lowest percentage of kills occurred on nonseeded areas suggests that density of herbage is not necessarily a factor in cattle damage to coniferous regeneration.

\section{Tree Heights as Affected by Grass Competition}

Lodgepole pine on both the ungrazed and unseeded treatments of Area 1 were significantly taller than on the other treatments (Table 3). Spruce showed no significant difference in height from either grazing or seeding treatments.

Table 3. Effects of seeding and grazing on height $(\mathrm{cm})$ of lodgepole pine and Engelmann spruce.

\begin{tabular}{|c|c|c|c|c|}
\hline & \multicolumn{2}{|c|}{ Lodgepole pine } & \multicolumn{2}{|c|}{ Engelmann spruce } \\
\hline & Grazed & Ungrazed & Grazed & Ungrazed \\
\hline \multicolumn{5}{|c|}{ Area 1 (planted) tree height after 6 years $(\mathrm{cm})$} \\
\hline Seeded & $179 \mathrm{~b}$ & $188 \mathrm{~b}$ & $98 \mathbf{a}$ & 95 a \\
\hline Not seeded & $191 \mathrm{~b}$ & $203 \mathrm{a}$ & $100 \mathrm{a}$ & $95 \mathrm{a}$ \\
\hline \multicolumn{5}{|c|}{ Area 3 (natural regeneration) tree height after 4 years $(\mathrm{cm})$} \\
\hline \multicolumn{5}{|c|}{ Plot 1.} \\
\hline Sceded & $31 \mathbf{a}$ & $28 \mathrm{~b}$ & & \\
\hline Not seeded & $35 \mathrm{a}$ & $36 \mathrm{a}$ & & \\
\hline \multicolumn{5}{|l|}{ Plot 2 . } \\
\hline Seeded & NR* & 20 & & \\
\hline Not seeded & 20 & 21 & & \\
\hline
\end{tabular}

* Not recorded

On Area 3, where no grazing occurred, tree reproduction on the seeded treatment was significantly less than that on the unseeded plots. However, there was no significant difference between the grazed and ungrazed treatments or the seeded vs. unseeded treatments when both were grazed. At a third location (Area 5), no significant differences were recorded between any of the treatments. Results of a growth-room trial indicated a significant reduction in pine survival and growth as density of grass increased (Clark and McLean 1975).

\section{Forage Production on Seeded Clearcuts}

Clipping trials over 5 years at five locations showed that 
seeded clearcut areas yielded two to four times more herbage than unseeded areas. The average yields of seeded species were between $590 \mathrm{~kg}$ and $1,540 \mathrm{~kg} / \mathrm{ha}$ with a maximum of 2,265 $\mathrm{kg} / \mathrm{ha}$. At all but one of the sites, the herbage yiclds increased progressively in each of the first 5 years. Experience on seeded wildfires in the district suggests that benefits can be expected to continue for up to 20 years following seeding before the tree canopy closes in. Similar longevity of grass stands can be expected on clearcut areas.

Crude protein levels of selected forage showed that, in most instances, pinegrass (Calamagrostis rubescens) was higher in protein content than timothy or orchardgrass from the start of grazing in late June until mid-August (Table 4). It appears that the seeded grasses developed and matured faster than the native pinegrass. The crude protein values of orchardgrass rose again in September, reflecting fall regrowth which was not apparent in the other species. The protein levels in shrubs did not drop in the fall as much as in grasses; for example, 8.8 and $6.6 \%$ in mid-August and mid-October as compared with an average of 3.4 and $5.5 \%$ for grasses during the same period. These protein levels for shrubs benefit the diets of cattle since these species are heavily browsed at that time.

Table 4. Crude protein levels $(\%)$ of selected grasses on Area 1 pasture at seven dates in 1976.

\begin{tabular}{lllllll}
\hline & July 12 & July 27 & Aug. 17 & Sept. 11 & Sept. 30 & Oct. 14 \\
\hline Pinegrass & 9.8 & 7.8 & 5.1 & 5.4 & 5.1 & 4.1 \\
Orchardgrass & 8.1 & 5.6 & 3.3 & 4.9 & 6.2 & 7.1 \\
Timothy & 6.6 & 5.4 & 3.4 & 2.4 & 2.6 & 4.3 \\
\hline
\end{tabular}

Cattle Weight Gains on Seeded Clearcuts

In the grazing trial on Area 1, the amount of damage to the coniferous reproduction was negligible despite the heavy rate of grazing. Although some year-to-year variation occurred in animal gains over the season, the trends for total gains were comparable. The 4-year average daily gains were $0.64 \mathrm{~kg}$ for calves and $0.13 \mathrm{~kg}$ for their dams (Table 5).

Performance of 2-year-old heifers was recorded for each season. Seasonal daily gains were low for these animals as compared with the 3- and 4-year-old cows. The 3-year daily average was $0.6 \mathrm{~kg}$ and $4.5 \mathrm{~kg}$ for calves and cows, respectively. The poor weight gains undoubtedly hampered their maturity and suppressed reproductive capacity. It was also noted that the rates of gain for the 3-year-old cows exceeded those of the other groups, during the initial weight period especially. This may be taken as evidence of compensatory gains. Using the average weight gains and stocking rates, the pastures returned $60 \mathrm{~kg}$ of beef/ha/year.

\section{Conclusions}

The Interior Douglasfir and Engelmann spruce-subalpine fir biogeoclimatic zones have potential for producing both trees for the forest industry and grass for the ranching industry. This is not to say that all clearcut areas in either zone are suitable or compatible for trees and grass. Each area must be rated according to soil capability, erosion hazards, regeneration objectives, and cattle management problems. Generally, trees and grass are compatible provided that cooperation exists between managers and users of the resources.

Variations in soils, elevation, topography, logging method, and post-logging site treatment between areas, or the climatic conditions between years, may significantly alter the relationship between grass and trees at any given time. It is difficult to apply general guidelines to specific situations. For example, site-preparation treatments vary greatly. It is, therefore, necessary to take a holistic approach to the question of tree-grass compatibility.

Despite the above reservations some general conclusions can be made:

The degree of forage utilization and the period of time when, and over which, the forage was utilized were the most critical factors in determining tree-cattle compatibility in this study. Results indicate that where numbers of cattle and the period of grazing were adequately controlled, damage to coniferous seedlings was negligible. On the other hand, where the period of grazing was too long, resulting in overutilization of forage, damage to the coniferous seedlings was extensive.

Where damage to lodgepole pine and spruce occurred, it was a result of repeated trampling rather than browsing. There were also situations such as overly dense, naturally regenerating lodgepole pine stands where forage was overutilized and large numbers of coniferous seedlings were damaged. This number was often insignificant in relation to the mortality occurring as a consequence of natural causes. The cases where extensive cattle damage occurred were usually where poor cattle management

Table 5. Four-year average daily gain (kg) by weigh periods for cows and calves and stocking rates (ha/animal unit month) on a seeded clearcut, 1973 to 1976.

\begin{tabular}{|c|c|c|c|c|c|}
\hline Year & Weigh periods & July to mid-Aug. & Mid-Aug. to Sept. 30 & Sept. 30 to late Oct. & Season \\
\hline 1973 & $\begin{array}{l}\text { Cows } \\
\text { Calves } \\
\text { Stocking rate }\end{array}$ & $\begin{array}{l}0.65 \\
0.84 \\
1.09\end{array}$ & $\begin{array}{l}-.06 \\
0.61 \\
0.66\end{array}$ & $\begin{array}{l}-.64 \\
0.31 \\
0.72\end{array}$ & $\begin{array}{l}0.03 \\
0.61 \\
0.69\end{array}$ \\
\hline 1974 & $\begin{array}{l}\text { Cows } \\
\text { Calves } \\
\text { Stocking rate }\end{array}$ & $\begin{array}{l}0.27 \\
0.83 \\
0.85\end{array}$ & $\begin{array}{l}0.05 \\
0.68 \\
0.67\end{array}$ & $\begin{array}{r}-.54 \\
0.27 \\
0.49\end{array}$ & $\begin{array}{l}0.07 \\
0.68 \\
0.57\end{array}$ \\
\hline 1975 & $\begin{array}{l}\text { Cows } \\
\text { Calves } \\
\text { Stocking rate }\end{array}$ & $\begin{array}{l}0.59 \\
0.79 \\
1.19\end{array}$ & $\begin{array}{l}0.11 \\
0.58 \\
0.76\end{array}$ & $\begin{array}{l}0.57 \\
0.16 \\
1.58\end{array}$ & $\begin{array}{l}0.17 \\
0.60 \\
0.87\end{array}$ \\
\hline 1976 & $\begin{array}{l}\text { Cows } \\
\text { Calves } \\
\text { Stocking rate }\end{array}$ & $\begin{array}{l}0.48 \\
0.82 \\
1.64\end{array}$ & $\begin{array}{l}0.29 \\
0.64 \\
0.57\end{array}$ & $\begin{array}{l}-.48 \\
0.44 \\
0.89\end{array}$ & $\begin{array}{l}0.25 \\
0.68 \\
0.85\end{array}$ \\
\hline $\begin{array}{l}\text { 4-year } \\
\text { Avg. }\end{array}$ & $\begin{array}{l}\text { Cows } \\
\text { Calves } \\
\text { Stocking rate }\end{array}$ & $\begin{array}{l}0.49 \\
0.82 \\
1.19\end{array}$ & $\begin{array}{l}0.04 \\
0.63 \\
0.66\end{array}$ & $\begin{array}{l}0.56 \\
0.29 \\
0.92\end{array}$ & $\begin{array}{l}0.13 \\
0.64 \\
0.73\end{array}$ \\
\hline
\end{tabular}


was evident. Clearcuts should be intensively grazed only for short periods of time. If there is a group of clearcuts in the area, grazing should be on a rotational basis if possible. Grazing is required to control any adverse effects of grass on conifers, but poorly controlled grazing has an adverse effect on coniferous reproduction.

Forage yields can be significantly increased on clearcuts by seeding domestic grasses. Overstocking by lodgepole pine on some sites may be reduced by temporarily grazing an area heavily. In spring, domestic grasses such as timothy and orchardgrass develop faster than pinegrass. Therefore, clearcuts seeded to timothy and orchardgrass should be grazed early in the season where possible. Furthermore, since orchardgrass produces good regrowth in the fall, it is often possible to again graze areas containing this species in late summer.

Light seeding rates are recommended to reduce early competition with tree seedlings, since most stands will thicken during the first 3 years following seeding.

\section{Literature Cited}

Clark, M.B., and A. McLean. 1974. Compatibility of grass seeding and coniferous regeneration on clearcuts in the south central interior of British Columbia. B.C. Forest Service Res. Note 63. 10 p.

Clark, M.B., and A. McLean. 1975. Growth of lodgepole pine seedlings in competition with different densities of grass. B.C. Forest Service Res. Note 70. $10 \mathrm{p}$.

Clark, M.B., and A. McLean. 1978. Compatibility of grass seeding and coniferous regeneration on clearcuts in the south central interior of British Columbia. B.C. Forest Service Res. Not. 83. 25 p. 